Original Article

\title{
Knowledge and attitudes about sexuality in the elderly with HIV/AIDS*
}

\author{
Conbecimento e atitudes sobre sexualidade em idosos portadores de HIV / AIDS \\ Conocimiento y actitudes sobre sexualidad en ancianos portadores de VIH/SIDA
}

\begin{abstract}
Meiry Fernanda Pinto Okuno ${ }^{1}$, Dayana Souza Fram ${ }^{1}$, Ruth Ester Assayag Batista $^{2}$, Dulce Aparecida Barbosa ${ }^{3}$, Angélica Gonçalves Silva Belasco ${ }^{4}$
\end{abstract}

\begin{abstract}
Objectives: Assess the knowledge and attitudes about sexuality in the elderly with HIV/AIDS served in a specialized ambulatory clinic; and identify the epidemiological profile of these patients. Methods: Cross-sectional, descriptive and analytical study with a sample of 148 people aged 50 years and over. The Aging Sexual Knowledge and Attitudes Scale was used to assess the knowledge and the attitudes about sexuality of the elderly. Results: The study included 148 elderly, male gender (63.5\%), single (30.5\%), retired and pensioners (53\%), low socioeconomic class $(60 \%)$, only $21 \%$ have completed the Secondary Education, monthly family income 3.3 minimum wages, time since diagnosis 156 months and predominant form of infection via sexual (66.2\%). ASKAS knowledge score was 32.2 and attitudes score was 15.5. There was significant association between the knowledge ASKAS with the female gender, being a widow and more than one comorbidity; and between the attitudes ASKAS with complete Secondary Education and physical activity. Conclusion: Patients with HIV/AIDS showed favorable knowledge and attitudes about sexuality in the elderly, and women that were housewives showed significant knowledge.
\end{abstract}

Keywords: Aging; Sexuality; Acquired immunodeficiency syndrome; Health knowledge, attitudes, practice

\section{RESUMO}

Objetivos: Avaliar o conhecimento e atitudes sobre sexualidade em idosos com HIV/AIDS atendidos em ambulatório especializado; e Identificar o perfil epidemiológico desses pacientes. Métodos: Estudo de corte transversal, descritivo e analítico com amostra de 148 pessoas com 50 anos ou mais. Utilizou-se a Aging Sexual Knowledge and Attitudes Scale para avaliar o conhecimento e atitudes sobre a sexualidade dos idosos. Resultados: Participaram do estudo 148 idosos, sexo masculino (63,5\%), solteiro (30,5\%), aposentados e pensionistas (53\%), classe econômica baixa $(60 \%)$, somente $21 \%$ possuíam até ensino médio completo, renda familiar mensal 3,3 salários, tempo de diagnóstico 156 meses e forma de contágio predominante via sexual (66,2\%). Escore da ASKAS de conhecimento foi 32,2 e de atitudes 15,5. Houve associação significante entre ASKAS conhecimento e gênero feminino, ser viúvo e mais de uma comorbidade e $A S K A S$ atitudes com ensino médio completo e atividade física. Conclusão: Pacientes com HIV/AIDS demonstraram conhecimento e atitudes favoráveis sobre a sexualidade no idoso, e mulheres donas de casa apresentaram conhecimento significante.

Descritores: Envelhecimento; Sexualidade; Síndrome de imunodeficiência adquirida; Conhecimentos, atitudes e prática em saúde

\section{RESUMEN}

Objetivos: Evaluar el conocimiento y actitudes sobre sexualidad en ancianos con VIH/SIDA atendidos en Consultorio Externo especializado; e Identificar el perfil epidemiológico de esos pacientes. Métodos: Estudio de corte transversal, descriptivo y analítico realizad con una muestra de 148 personas con 50 años o más. Se utilizó la Aging Sexual Knowledge and Attitudes Scale para evaluar el conocimiento y actitudes sobre la sexualidad de los ancianos. Resultados: Participaron en el estudio 148 ancianos, sexo masculino (63,5\%), solteros (30,5\%), jubilados y cesantes (53\%), clase económica baja (60\%), solamente $21 \%$ poseían hasta primaria completa, ingreso familiar mensual 3,3 salarios, tiempo de diagnóstico 156 meses y forma de contagio predominante vía sexual (66,2\%). Score de la $A S K A S$ de conocimiento fue de 32,2 y de actitudes 15,5. Hubo asociación significativa entre $A S K A S$ conocimiento y género femenino, ser viudo y más de una comorbilidad y $A S K A S$ actitudes con primaria completa y actividad física. Conclusión: Pacientes con VIH/SIDA demostraron conocimiento y actitudes favorables sobre la sexualidad en el anciano, y mujeres amas de casa presentaron conocimiento significativo.

Descriptores: Envejecimiento; Sexualidad; Síndrome de imunodeficiência adquirida; Conocimientos, actitudes y prática en salud

* A study conducted at the Clinic of Infectious Diseases, Federal University of São Paulo - UNIFESP - São Paulo (SP), Brazil.

${ }^{1}$ Masters in Science, Federal University of São Paulo - UNIFESP - São Paulo (SP), Brazil (CAPES Scholarship)

${ }^{2}$ PhD in Science. Associate Professor, Paulista School of Nursing, Federal University of São Paulo - UNIFESP - São Paulo (SP), Brazil

${ }^{3}$ Habilitation (professorship). Associate Professor, Paulista School of Nursing, Federal University of São Paulo - UNIFESP - São Paulo (SP), Brazil

${ }^{4}$ Post PhD in Science. Associate Professor, Paulista School of Nursing, Federal Universty of São Paulo - UNIFESP - São Paulo (SP), Brazil 


\section{INTRODUCTION}

The epidemic of Acquired Immunodeficiency Syndrome (AIDS) nowadays is a great challenge in the field of health worldwide. Approximately 33 million people live with the Human Immunodeficiency Virus in several countries. In 2008 alone, the number of new cases reported was 2.7 million and other 2 million died as a result of AIDS, the majority due to inadequate access to health services ${ }^{(1)}$.

The sub-Saharan Africa is the region most affected by the epidemic, thus around $67 \%$ of the people infected with HIV and $72 \%$ of AIDS deaths occurred in this region in $2008^{(1)}$.

In Brazil, between the year 1980 and June of 2011, 397.662 cases of AIDS were identified in people of the male gender and 210.538 in the female ${ }^{(2)}$. The proportion of reported cases between the genders male and female has considerably decreased since the beginning of the epidemic until nowadays, and the values of the ratio went from 24:1 in 1985, to 6:1 in 1990, and stood at $2: 1$ since $1997^{(3)}$.

In Brazil, people aged between 40 and 49 years old were the most affected in the period between 1980 and $2010^{(4)}$. However, over the last years there has been an increase in the incidence of the disease in individuals aged 50 and over ${ }^{(5)}$. Although in Brazil people aged under 60 years are not considered elderly, in the majority of the epidemiological studies those with HIV/AIDS started to be classified as so by the Centers for Disease and Control and Prevention (CDC), due to the commitment generated by the disease and the small number of infected people aged over 50 years ${ }^{(6)}$.

Since the first reported case of HIV infection, the epidemiology of the disease has suffered continuous changes because of the increasing number of elderly affected, which led to the use of the term "aging epidemic"(6).

The development of the antiretroviral therapy for the treatment of the HIV infection is one of the greatest achievements of modern medicine. In a short period of time the survival rate of infected people went from years to decades ${ }^{(7)}$. Currently the disease is classified as chronic and countless virus carriers live long periods without presenting symptoms of the disease. Some advances in the methods of diagnosis, more efficient medication and experience obtained over the years by health professionals are factors that have positively influenced for a higher survival rate and a better quality of life when compared with the beginning of the epidemic ${ }^{(8)}$.

Today, the majority of the elderly infected by HIV is male and states to have acquired the disease through sexual contact ${ }^{(6)}$. New possibilities for experiencing the sexuality have made older people more vulnerable to sexually transmitted diseases (STDs) and concomitantly, the incidence of AIDS has increased among people aged 50 years and over ${ }^{(9)}$.

Despite the numerous changes in paradigms related to sexuality, great part of the society does not see it as healthy and natural for the elderly. The prejudice and lack of information reinforce the idea of an asexual old age, which increases the vulnerability of the elderly to STDs. National campaigns and actions to promote and protect health conducted since 2008 have diminished the invisibility of the HIV transmission in the geriatric population ${ }^{(9,10)}$.

The HIV has well defined modes of transmission and it is only transmitted through human specific and identifiable actions, all subject to the control and action of man, therefore, AIDS is preventable and controllable ${ }^{(11)}$.

According with the World Health Organization, until 2005 Brazil will be the sixth country of the world in number of elderly ${ }^{(12)}$. In view of the increase in the life expectancy of the Brazilian population, the increase of HIV infected people in older age groups and the few studies on the knowledge and attitudes towards sexuality, it was identified the importance of studying this subject. The results may contribute with the identification of an epidemiological profile, the knowledge and attitudes on sexuality of HIV/AIDS infected people and consequently subsidize and stimulate actions in health education, searching for the disease prevention and for alternatives to solve the difficulties experienced in the exercise of sexuality of people with HIV/AIDS aged 50 and over, classified as elderly in this study.

\section{OBJECTIVES}

Assess the knowledge and attitudes on sexuality of the elderly diagnosed with HIV/AIDS served in a specialized ambulatory clinic and identify the epidemiological profile of these patients.

\section{METHODS}

Cross-sectional, analytical and epidemiological study conducted in the ambulatory clinic coordinated by the Division of Infectious and Parasitic Diseases of the Federal University of São Paulo (UNIFESP), between May and November, 2011. In this study were included people with HIV/AIDS aged 50 and over that, according with the CDC and UNAIDS classification, are considered elderly ${ }^{(6-13)}$.

The research sample consisted of 148 people with HIV/AIDS served in the ambulatory clinic of both genders, with a confirmed diagnosis of HIV infection, 
aged from 50 years, without cognitive impairment, who agreed to participate in the study after the explanation of the purposes of the research and the signature of a Term of Consent. The research project was approved by the Ethics Committee in Research of the UNIFESP under number CEP 0182/11.

To obtain the data, it was used a questionnaire with sociodemographic information (age, gender, education, marital status, occupation), economic information (Brazilian Economic Classification Criterion - Critério de Classificação Econômica Brasil/ CCEB), time since disease diagnosis, means of transmission and comorbidities. The CCEB elaborated by the Brazilian Association of Research Companies ${ }^{(14)}$ was obtained by converting the sum of points of level of education for the researched patient and the quantity of consumer goods in each household, in one of the socioeconomic classes (A to E). The instrument used was the Aging Sexual Knowledge and Attitudes Scale - ASKAS ${ }^{(15)}$, composed of 20 questions in the construct "knowledge" and eight in the construct "attitudes". In the first part a low score indicates high knowledge on sexuality at an old age and the answer alternatives are: true $=1$ point, false $=2$ points and I don't know $=3$ points. In the second part of the scale that assesses attitudes, a low score indicates a more favorable attitude towards sexuality of the elderly. The second part consists of a 5-point Likert scale (strongly disagree $=1$ point; partially disagree $=2$ points; neither agree nor disagree $=3$ points; partially agree $=4$ points and strongly agree $=5$ points).

The participants were invited to join the study on the days of attendance to the clinic for routine exams or medical appointments. The interview took place on the same day, in a private room, without the presence of a companion. The reading of the instruments was done by the same researcher, in a single moment, with an average duration of 40 minutes.

The analysis of the ASKAS variables of knowledge and attitudes was made using non-parametric tests because it did not follow a normal curve. In the case of variables with two categories, the MannWhitney test was applied and when the number of categories was equal three or greater, the Kruskal-Wallis test was applied, followed by the Newman-Keuls test, when necessary. The level of significance was set at $\mathrm{p}<0.05$ and the data were computed in the software Statistica version 10.

\section{RESULTS}

The sociodemographic and economic characteristics of the elderly patients with HIV/AIDS, participants of the study, are shown in Table 1.
Table 1. Sociodemographic and economic characteristics of the elderly patients diagnosed with HIV/AIDS - UNIFESP/ HSP - May to November, 2011. ( $=148)$

\begin{tabular}{lc}
\hline Characteristics & $\mathbf{n}(\%)$ \\
\hline Gender & \\
Male & $94(63.5)$ \\
$\quad$ Female & $54(36.5)$ \\
Age group & \\
50 to 59 years & $93(63.0)$ \\
60 years and over & $55(37.0)$
\end{tabular}

Skin color

White

$99(67.0)$

Black

$14(9.0)$

Others

\section{Marital status}

Married

$40(27.0)$

Single

Widower/widow

26(17.5)

Divorced/separated

Education

Illiterate

Incomplete primary school

Complete primary school

Complete secondary school

\section{Occupation}

Unemployed

$8(5.0)$

Housewife

Retired/Pensioner

Employed

Socioeconomic class

$$
\begin{array}{lc}
\mathrm{A}+\mathrm{B} & 59(40.0) \\
\mathrm{C}+\mathrm{D}+\mathrm{E} & 89(60.0) \\
\text { Individual income } & 2.3(0-16.5) \\
\text { Family income } & 3.3(0.5-18.3)
\end{array}
$$

Values expressed as numbers $(\%)$ and median (minimum - maximum). The individual and family incomes are given in minimum wage (MW) $1 \mathrm{MW}=\mathrm{R} \$ 545,00$. 
The data in the Table 2 show the comorbidities, the means of transmission and physical activity of the patients diagnosed with HIV/AIDS.

Table 2. Comorbidities, means of transmission and physical activity of the patients diagnosed with HIV/AIDS - UNIFESP/ HSP - May to November, 2011 ( $\mathrm{N}=148)$

\begin{tabular}{lc}
\hline Characteristics & $\mathbf{n ~ ( \% )}$ \\
\hline Comorbidities * & \\
1 or more & $102(69.0)$ \\
$\quad$ None & $46(31.0)$ \\
Time since diagnosis (months) & $156(3-360)$ \\
Means of transmission & \\
$\quad$ Sexual intercourse & $98(66.2)$ \\
Other means** & $50(33.8)$ \\
Physical activity & \\
Yes & $71(48.0)$ \\
No & $77(52.0)$ \\
\hline
\end{tabular}

Note Values expressed as numbers (\%) and median (minimum - maximum). *Comorbidities: hypertension, diabetes mellitus, hypercholesterolemia, myocardial infarction acute, hyperthyroidism and peripheral vascular disease. $* *$ Other means of transmission: blood transfusion, injecting drugs, needlestick accidents and dental treatment. Physical activity: walking, cycling, swimming and the gym.

The data in Table 3 show the scores statistically significant among the scores of the The Aging Sexual Knowledge and Attitudes Scale (ASKAS) and the sociodemographic, economic and morbid characteristics of the study participants.

The illiterate individuals or with incomplete primary school, and those who did not practice physical activities held significantly less favorable attitudes towards sexuality of the elderly.

Table 3. Knowledge and attitude scores of the ASKAS, according to the sociodemographic, economic and morbid variables of the elderly patients of the study - UNIFESP/HSP - May to November, 2011

\begin{tabular}{lcccc}
\hline Characteristics & Knowledge & $\begin{array}{c}\mathbf{P} \\
\text { value }\end{array}$ & Attitudes & $\begin{array}{c}\mathbf{P} \\
\text { value }\end{array}$ \\
\hline Gender & & & & \\
$\quad$ Male & $30.1 \pm 5.0$ & $<0.001$ & $14.7 \pm 6.7$ & 0.067 \\
$\quad$ Female & $35.9 \pm 8.5$ & & $16.9 \pm 7.4$ & \\
Age group (years) & & & & \\
$\quad 50-59$ & $32.1 \pm 7.1$ & 0.753 & $14.7 \pm 6.4$ & 0.098 \\
60 and over & $32.4 \pm 7.1$ & & $17.0 \pm 7.9$ &
\end{tabular}

Time since diagnosis (median 13 years)

$\begin{array}{lllll}\begin{array}{l}\text { Bellow the } \\ \text { median }\end{array} & 32.3 \pm 6.7 & 0.831 & 15.9 \pm 6.5 & 0.223 \\ \text { Median or more } & 32.2 \pm 7.4 & & 15.2 \pm 7.6 & \end{array}$

\section{Marital status}

\begin{tabular}{|c|c|c|c|}
\hline Married & $30.5 \pm 6.4$ & 0.048 & $15.7 \pm 7.4$ \\
\hline Single & $31.1 \pm 5.8$ & & $14.5 \pm 6.6$ \\
\hline $\begin{array}{l}\text { Widow/ } \\
\text { widower }\end{array}$ & $36.3 \pm 9.5$ & & $16.3 \pm 7.8$ \\
\hline $\begin{array}{l}\text { Divorced/ } \\
\text { separated }\end{array}$ & $32.6 \pm 6.3$ & & $16.1 \pm 6.7$ \\
\hline
\end{tabular}

Education

\begin{tabular}{|c|c|c|c|c|}
\hline Illiterate & $32.7 \pm 6.8$ & 0.386 & $18.0 \pm 7.6$ & 0.022 \\
\hline $\begin{array}{l}\text { Incomplete } \\
\text { primary school }\end{array}$ & $32.8 \pm 7.2$ & & $15.1 \pm 6.7$ & \\
\hline $\begin{array}{l}\text { Complete } \\
\text { primary school }\end{array}$ & $32.4 \pm 7.3$ & & $15.4 \pm 7.1$ & \\
\hline $\begin{array}{l}\text { Complete } \\
\text { secondary } \\
\text { school }\end{array}$ & $30.8 \pm 7.1$ & & $12.9 \pm 5.6$ & \\
\hline \multicolumn{5}{|l|}{ ccupation } \\
\hline Unemployed & $32.4 \pm 6.2$ & 0.02 & $16.5 \pm 7.7$ & 0.349 \\
\hline Housewife & $39.3 \pm 9.0$ & & $20.0 \pm 6.2$ & \\
\hline $\begin{array}{l}\text { Retired/ } \\
\text { pensioner }\end{array}$ & $32.9 \pm 7.1$ & & $15.3 \pm 7.3$ & \\
\hline Employed & $30.5 \pm 6.4$ & & $15.3 \pm 6.7$ & \\
\hline
\end{tabular}

Socioeconomic class

\begin{tabular}{|c|c|c|c|}
\hline A & $32.0 \pm 10.3$ & 0.595 & $11.0 \pm 3.2$ \\
\hline B & $31.7 \pm 6.8$ & & $14.0 \pm 6.0$ \\
\hline $\mathrm{C}$ & $32.6 \pm 6.3$ & & $16.5 \pm 7.1$ \\
\hline $\mathrm{D}$ & $32.1 \pm 9.7$ & & $17.2 \pm 9.5$ \\
\hline $\mathrm{E}$ & $34.3 \pm 7.6$ & & $20.7 \pm 6.4$ \\
\hline
\end{tabular}

Individual income (median $=2.3 \mathrm{MW})$

$\begin{array}{lllll}\begin{array}{l}\text { Bellow the } \\ \text { median }\end{array} & 32.8 \pm 7.0 & 0.273 & 16.4 \pm 7.9 & 0.198 \\ \text { Median or more } & 31.7 \pm 7.1 & & 14.4 \pm 6.1 & \end{array}$

Family income (median=3.3 MW)

Bellow the median

$32.5 \pm 6.8$
$32.0 \pm 7.3$ 0.456

$16.2 \pm 7.7 \quad 0.308$

Median or more

$14.6 \pm 6.4$

Morbidity

$\begin{array}{lllll}\text { None } & 30.2 \pm 5.1 & 0.033 & 15.0 \pm 7.4 & 0.378 \\ \begin{array}{l}\text { 1 or more } \\ \text { Means of }\end{array} & 33.1 \pm 7.6 & & 15.8 \pm 6.9 & \\ \begin{array}{l}\text { ansmission } \\ \text { Sexual } \\ \text { intercourse }\end{array} & 32.2 \pm 6.7 & 0.78 & 16.0 \pm 7.3 & 0.289 \\ \text { Others } & 32.3 \pm 7.9 & & 14.7 \pm 6.6 & \\ \text { hysical activity } & & & & \\ \text { No } & 33.4 \pm 7.7 & 0.062 & 16.8 \pm 7.0 & 0.012 \\ \text { Yes } & 30.9 \pm 6.1 & & 14.2 \pm 6.9 & \end{array}$

ASKAS (studied population)

$32.2 \pm 7.1$

Values expressed as mean \pm DP, the Kruskal-Wallis test was used for the variables marital status, education, occupation and socioeconomic class, the Mann-Whitney test was used for the variables gender, age group, physical activity, individual and family incomes, significance level $\mathrm{p}<0.05$. 


\section{DISCUSSION}

In this research, in the sample, it is observed that $62.8 \%$ of the patients were male. However, it is currently noticeable the increase of AIDS cases among women ${ }^{(16)}$ who, in general, have lower income, a more susceptible health and succumb to this disease faster than men ${ }^{(17)}$.

The improved quality of life with access to health services, medication, better nutrition, leisure and general wellbeing conditions, as well as recent advances of the pharmaceutical industry and the medicine, allow the extension of an active sex life and, in association with the demystification of the gender, make the elderly more vulnerable to sexually transmitted infections, among them, the HIV/AIDS ${ }^{(18)}$. The majority of the respondents of this study $(66.2 \%)$ informed to have acquired the disease through sex. This is in line with data of the Brazilian Epidemiological Bulletin of 2010, and recent studies that show sex as the prevalent means of transmission among individuals older than 13 years ${ }^{(4,17,19)}$.

In this study the assessed individuals showed an average score of 32.2 on the ASKAS scale for knowledge on sexuality, which ranges between 20 and 60. Another study ${ }^{(20)}$ assessed the knowledge of university students of the health area and came to an average score of 33.7 points for those who lived with elderly relatives and of 36.9 points for those who had no experience with the elderly. These results suggest that the elderly with HIV may have better knowledge when compared with university students in the health field, once the lower the score the greater the knowledge on sexuality.

Regarding the ASKAS scale for attitudes, the subjects of this study had an average score of 15.5 on a scale that ranges from 8 to 40 , which corresponds to $23.4 \%$ of the possible score. The same survey with Brazilian university students ${ }^{(20)}$ analyzed the results based on the answer of each question, which made it impossible to compare the data with this study, that analyzed the global result of the questionnaire. However, another American study with gynecologists ${ }^{(21)}$ had an average score of 81 on the American ASKAS scale, in which the scores range from 26 to 182 , representing $35.2 \%$ of the possible score, what showed that the population of the present study had a more favorable attitude towards the sexuality of the elderly than the gynecologists. In literature, studies assessing the knowledge and attitude of the patients were not found, only surveys with students and health professionals ${ }^{(21,22)}$. These results are the first to be obtained from the application of this instrument in this population.

In the research with university students of the health field it was observed that their knowledge about sexuality was reasonable ${ }^{(20)}$. The elderly in this study had a better knowledge than the group of students. The knowledge about sexuality differs from the one about AIDS. The study that compared the perception of elderly men and young adults about AIDS observed a lower knowledge of AIDS on the elderly. Hence a better knowledge on sexuality does not necessarily mean a better understanding of the transmission, preventive behavior, diagnosis and treatment of $\operatorname{AIDS}^{(23)}$.

People with a more advanced level of education have a more favorable attitude towards the sexuality of the elderly, as they tend to assimilate the information better, have more access to health services and to purchase of condoms ${ }^{(24)}$. Furthermore, the access to education is linked with the decrease of risk behavior ${ }^{(1)}$.

In this study the individuals who practiced physical exercise demonstrated a better attitude about the sexuality of the elderly. This data is in accordance with the study that indicated the possibility of a relationship between physical exercise practice and more favorable attitudes towards sexuality at an old age. In general, the more sexually active elderly are the ones who regularly practice physical exercise ${ }^{(25)}$.

The data in Table 3 demonstrates that women, housewives, widow/widowers and patients presenting associated comorbidities showed significantly greater knowledge about sexuality of the elderly. The knowledge of the elderly on STD/AIDS, in general, comes from sources of information such as television, radio and newspapers ${ }^{(24)}$. In the same survey, women stood out for the higher number of positive answers when questioned about the means of transmission of $\operatorname{AIDS}^{(24)}$.

In this research the widows/widowers showed more knowledge about sexuality; this result corroborates the findings of the study that, for the elderly, the widowhood means autonomy, freedom and participation in elderly groups. It favors the occurrence of affective encounters and increases the possibility of the elderly to relate sexually with somebody else ${ }^{(26)}$. To watch more television and participate of elderly groups may partly justify the greater knowledge of the widows/widowers and housewives about sexuality.

The majority of patients of this study belonged to the socioeconomic classes C, D and E. This may be related to the socioeconomic profile of the users of public health services in Brazil ${ }^{(27)}$.

There is a close relation between unfavorable socioeconomic indicators and the increase of HIV/ AIDS incidence. Individuals with low education, low income and residents of geographical areas with low human development index have been the most affected by the disease ${ }^{(16)}$.

The low level of knowledge about sexuality of the elderly demonstrated by the participants of this study highlights the need for new actions and programs to prevent HIV/AIDS as, although the incidence of the 
disease is increasing among the elderly, they normally do not see themselves as a risk group ${ }^{(28)}$.

In Brazil, transformations have been recorded on the epidemiological profile of people with HIV/AIDS, being the most significants the feminization, the heterosexualization, the interiorization, the ageing, the low education and the pauperization ${ }^{(29)}$.

In this study the population consisted of $67 \%$ white, 9\% black, 23\% mixed and 1\% Asian. A different result was found in literature, which reveals greater vulnerability of black to HIV/AIDS in Brazil ${ }^{(16)}$.

In the study conducted in the United States of America, that estimated the incidence of HIV between 2006 and 2009, it was observed that the only group that showed an increase in the incidence rate was the young black males who had sexual intercourse with other men ${ }^{(19)}$. Also in Latin America, HIV transmission among men who have sex with men is the most prevalent, followed by heterosexual transmission ${ }^{(30)}$.

The construction of knowledge about AIDS is not restricted only to informative matters, but also involves the understanding and the ability to assimilate information about it ${ }^{(31)}$. The population of this study showed knowledge and attitude more favorable towards the sexuality of the elderly. It is possible that due to the knowledge of this population about their HIV infection, they seek health services for treatment and monitoring. This can allow a greater access to information about sexuality and STD prevention measures.

The main limitation of the present study was the fact that it was conducted in a single centre and, therefore, reflected a local experience. Besides that, for being a university that provides assistance for patients in the

\section{REFERENCES}

1. Nações Unidas Brasil. Programa Conjunto das Nações Unidades sobre HIV-AIDS.. A ONU e a resposta à aids no Brasil. $2^{a}$ ed. [Internet]. Brasília(DF): UNAIDS [citado 2011 Dez]. Disponível em: http://www.unaids. org.br/biblioteca/Folder $\% 20 \mathrm{~A} \% 20$ ONU $\% 20 \mathrm{e} \% 20 \mathrm{a} \% 20$ Resposta $\% 20 \%$ E0\%20aids $\% 20$ no $\% 20$ Brasil $\% 202 \%$ AA $\% 20$ Edi $\%$ E7\%E30\%20FINAL.pdf

2. Brasil. Ministério da Saúde. Boletim Epidemiológico AIDS/ DST. 2012; 8(1), 26 à $52^{\mathrm{a}}$ semanas epidemiológicas, julho a dezembro de 2010; $01^{\mathrm{a}}$ à $26^{\mathrm{a}}$ semanas epidemiológicas, janeiro a junho de 2011.

3. Brasil. Ministério da Saúde. Boletim Epidemiológico AIDS. 2000; 13(1): 15-56, SE 48/99 a 22/00.

4. Brasil. Ministério da Saúde. Boletim Epidemiológico AIDS/ DST. 2010; 7(1), 27 à $52^{\mathrm{a}}$ semanas epidemiológicas, julho a dezembro de 2009 e $01^{\mathrm{a}}$ à $26^{\mathrm{a}}$ semanas epidemiológicas, janeiro a junho de 2010 .

5. Brasil. Ministério da Saúde. Boletim Epidemiológico AIDS/ DST. 2008; 5(1), $27^{\mathrm{a}}$ à $52^{\mathrm{a}}$ semanas epidemiológicas, julho a dezembro de 2007 e $01^{\mathrm{a}}$ à $26^{\mathrm{a}}$ semanas epidemiológicas, janeiro a junho de 2008. public and private system, it may not represent the reality of other regions of the country.

However, it is noteworthy that this is the first study about knowledge and attitudes on sexuality of the elderly that uses the ASKAS instrument in this population in Brazil.

The main limitation of the present study is the fact of being conducted in a single centre, a university that provides assistance for patients of the public and private systems so it does not represent other realities. It is noteworthy that the approach with the elderly about sexuality permeates social prejudices, which hampers this kind of research.

The results of this study contribute to subsidize public policies focused on the promotion and prevention of health of the elderly, as well as adding essential information for prevention of HIV/AIDS in this age group. Once sex is the major means of transmission and of easy prevention, it is essential to approach this subject with this population.

The aging population and the need for updates on HIV/AIDS with the elderly justify the reading of this article, especially by health professionals.

\section{CONCLUSIONS}

The results of this study allowed the conclusion that women, housewives, widows/widowers and patients with associated comorbidities showed significantly greater knowledge about the sexuality and those with higher level of education and that practiced physical activity had a more favorable attitude towards sexuality of the elderly.

6. Blanco JR, Caro AM, Pérez-Cachafeiro S, Gutiérrez F, Iribarren JA, González-García J, et al. HIV Infection and Aging. AIDS Rev. 2010;12(4):218-30.

7. Deeks SG. HIV infection, inflammation, immunosenescence, and Aging. Annu Rev Med. 2011;62:141-55.

8. Maliska IC, Padilha MI. AIDS: a experiência da doença e a construção do itinerário terapêutico. Rev Eletrônica Enferm [Internet]. 2007[citado 2012 Out 23];9(3):687-99. Disponível em: http://www.revistas.ufg.br/index.php/fen/article/view/7449

9. Santos AF, Assis M. [Vulnerability of the elderly to hiv/aids: public politics and health professionals in the context of integral care: a literature review]. Rev Bras Geriatr Gerontol. 2011;14(1):147-58. Portuguese.

10. Paz AA, Santos BR, Eidt OR. [Vulnerability and aging in the health context]. Acta Paul Enferm. 2006;19(3):338-42. Portuguese.

11. United Nations. Joint United Nations Programme on HIV/ AIDS - UNAIDS. 2006 Report on the global AIDS epidemic. A UNAIDS 10th anniversary special edition [Internet] [cited 2011 Dec 28]. Available from: http://www.unaids. org/en/media/unaids/contentassets/dataimport/pub/ 
report/2006/2006_gr_en.pdf

12. World Health Organization. Envelhecimento ativo: uma política de saúde. Brasília: WHO; 2005.

13. United Nations. Joint United Nations Programme on HIV/ AIDS - UNAIDS. Report on the global HIV/AIDS epidemic June 1998 [Internet] [cited 2011 Dez 28]. Available from: http:// www.unaids.org/en/media/unaids/contentassets/dataimport/ pub/report/1998/19981125_global_epidemic_report_en.pdf

14. Associação Brasileira de Empresas de Pesquisa. Critério de classificação econômica Brasil [Internet]. 2003 [citado 2011 Dez 28]. Disponível em: http://www.abep.org/novo/ Content.aspx?ContentID $=302$

15. Viana HB, Guirardello EB, Madruga VA. [Translation and cross-cultural adaptation of the Askas - Aging sexual knowledge and attitudes scale in brazilian elderly]. Texto \& Contexto Enferm. 2010;19(2):238-45. Portuguese.

16. Miranda-Ribeiro P, Simão AB, Caetano AJ, Lacerda MA, Abreu e Torres ME. Profiles of female vulnerability to HIV/AIDS in Belo Horizonte and Recife: a comparison of white and black/mixed women]. Saude Soc. 2010;19 (Suppl 2):21-35. Portuguese.

17. Beaulaurier RL, Craig SL, De La Rosa M. Older latina women and HIV/AIDS: an examination of sexuality and culture as they relate to risk and protective factors. J Gerontol Soc Work. 2009;52(1):48-63.

18. Lazzarotto AR, Kramer AS, Hädrich M, Tonin M, Caputo P, Sprinz E. [The knowledge of the aged about HIV/AIDS: epidemiologic study in Vale do Rio dos Sinos, Rio Grande do Sul, Brazil]. Ciênc Saúde Coletiva. 2008;13(6):1833-40. Portuguese.

19. Prejean J, Song R, Hernandez A, Ziebell R, Green T, Walker F, et al. Estimated HIV incidence in the United States, 2006-2009. PLoS One. 2011;6(8):e17502.

20. Rabelo DF, Lima CF. Conhecimento e atitude de futuros profissionais da saúde em relação à sexualidade na velhice. Rev Kairós Gerontol. 2011;14(5):163-80.
21. Langer-Most O, Langer N. Aging and sexuality: how much do gynecologists know and care?. J Women Aging. 2010;22(4):283-9.

22. Dogan S, Demir B, Eker E, Karim S. Knowledge and attitudes of doctors toward the sexuality of older people in Turkey. Int Psychogeriatr. 2008;20(5):1019-27.

23. Melo HM, Leal MC, Marques AP, Marino JG. [Awareness about Aids among elderly males and young adults: a study of the perception of this disease]. Ciênc Saúde Coletiva. 2012;17(1):43-53. Portuguese.

24. Medeiros KC, Leal MC, Marques AP, Marino JG. [Aids information among elderly people attending the health family program in Brazil]. Geriatr Gerontol.2008;2(2):53-8. Portuguese.

25. Viana HB, Madruga VA. Sexualidade, qualidade de vida e atividade física no envelhecimento. Conexões. 2008(6):222-32.

26. Leite MT, Moura C, Berlezi EM. Doenças sexualmente transmissíveis e HIV/AIDS na opinião de idosos que participam de grupos de terceira idade. Rev Bras Geriatr Gerontol. 2007;10(3).

27. Moimaz SA, Marques JA, Saliba O, Garbin CA, Zina LG, Saliba NA. [Satisfaction and perception of SUS's users about public health care]. Physis. 2010,20(4):1419-40. Portuguese.

28. Falvo N, Norman S. Never too old to learn: the impact of an HIV/AIDS education program on older adults' knowledge. Clin Gerontol. 2004;27(1/2):103-17.

29. Gomes AM, Silva EM, Oliveira DC. Social representations of AIDS and their quotidian interfaces for people living with HIV. Rev Latinoam Enferm. 2011;19(3):485-92.

30. Centers for Disease Control. HIV/AIDS surveillance report. Atlanta(GA): US Department of Health and Human Services; 2003.

31. Ferreira MP; Grupo de Estudos de População, Sexualidade e Aids. Knowledge and risk perception on HIV/AIDS by Brazilian population, 1998 and 2005. Rev Saúde Pública. 2008;42 (Suppl 1):65-71. 